\title{
In Memoriam: Orie L. Loucks (1931-2016)
}

\author{
Jianguo Wu
}

Received: 5 December 2016/Accepted: 11 December 2016/Published online: 20 December 2016

(C) Springer Science+Business Media Dordrecht 2016

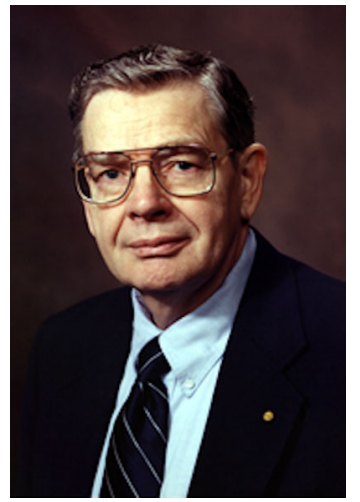

The global landscape of ecology has just lost an important patch. Dr. Orie L. Loucks, a great ecologist and a devoted environmental scientist, passed away in Waunakee, Wisconsin on September 10, 2016. He is survived by his loving wife of 60 years, Elinor, and their children and grandchildren. I was deeply saddened by the passing of Dr. Loucks - a revered scientist, a great mentor, a dear friend.

Born in Minden, Ontario, Canada on October 2, 1931, Orie Loucks obtained his Bachelor's degree in 1953 and Master's degree in 1955 from School of Forestry of University of Toronto. He was Research

J. Wu ( $\triangle)$

School of Life Sciences and School of Sustainability, Arizona State University, Tempe, AZ 85287, USA e-mail: Jingle.Wu@asu.edu
Officer in Canada Department of Forestry, Fredericton, New Brunswick between 1955 and 1962. He did his Ph.D. research under the guidance of John T. Curtis in University of Wisconsin, Madison between 1957 and 1960. Dr. Loucks returned, as Assistant Professor, to Department of Botany, University of Wisconsin in 1962 where he was promoted to Associate Professor in 1964 and Professor in 1967. He was a prominent member of the Wisconsin School of North American ecology in its heyday (Mladenoff and Burgess 1993). Dr. Loucks became the Science Director of The Institute of Ecology, Indianapolis in 1978, and the Director of Holcomb Research Institute, Butler University, Indianapolis in 1983. He joined the faculty of Miami University, Oxford in 1989 as Ohio Eminent Scholar in Applied Ecosystem Studies, and became Professor Emeritus in 2002.

Dr. Loucks had a long and stellar record of professional and public services, including National Academy of Sciences Board on Water Science and Technology (1982-1985), Co-chair of the joint NRCNAS/Royal Society of Canada study reviewing the 1978 Great Lakes Water Quality Agreement (1984-1985), President of the Association of Ecosystem Research Centers (1990-1992), Board of Governors, The Nature Conservancy (1984-1994), Science Advisory Board, International Joint Commission (1991-1994), and Chair of the U.S. Vegetation Classification Panel of the Ecological Society of America (1994-1997). 
He was bestowed with numerous honors and awards, including George Mercer Award from Ecological Society of America (1964), Elected Fellow, American Association for the Advancement of Science (1987), Distinguished Service Award from American Institute of Biological Sciences (1994), The Nature Conservancy Oak Leaf Award (1994), Elected Fellow, Ohio Academy of Science (2000), and National Conservation Achievement Award in Science from National Wildlife Federation (2000).

As one of the most innovative and interdisciplinary ecologists in North America, Dr. Loucks made important contributions to a number of scientific fields, including plant ecology/vegetation science (Loucks 1962, 1970; Knight and Loucks 1969; Peet and Loucks 1977; Canham and Loucks 1984; Loucks et al. 1985; Jennings et al. 2009), ecosystem modeling (MacCormick et al. 1974; Watson and Loucks 1979), watershed/regional ecology (Loucks 1985, 1990a, b), air pollution (Loucks and Armentano 1982, Loucks and Galss 1986), agricultural and urban systems (Loucks 1977, 1994), and sustainability science (Loucks 1994; Loucks et al. 1999; Loucks and Gorman 2004). His more than 200 journal articles, book chapters, and research reports cut across traditional disciplinary silos and articulated their connections in theory and practice. Dr. Loucks' studies explicitly linked ecological patterns with environmental scalars, as well as terrestrial with aquatic systems, on landscape and regional scales.

From 1969 to 1973 , he headed an interdisciplinary watershed study of the Lake Wingra basin in Wisconsin, as part of the US/International Biological Program, linking ecology with hydrology, meteorology, chemistry, soil science, geography, and systems modeling. As the Director of Holcomb Research Institute, he guided the development of cross-disciplinary programs in Water Sciences, Biotic Resources, and Environmental Economics and Policy. At Miami University, he worked extensively with colleagues in multiple disciplines to develop a landmark course in sustainability, and coauthored the textbook on sustainability perspectives for resources and business (Loucks et al. 1999).

To many of us, Dr. Loucks was a great mentor and wonderful colleague. I first met Dr. Loucks in 1989 at Miami University where I was a graduate student. He soon became my role model because of his enormous knowledge, intellectual prowess, and professional charisma. I learned a great deal from his classes, academic advice, and long-term collaborations in research. His Ecosystem Ecology (co-taught with Dr. Gary Barrett) and Ecosystem Theory and Problem Solving were extremely comprehensive and thoughtprovoking. Between 1990 and 1991, I worked with him on the project, "Grasslands and Grassland Sciences in Northern China", organized by the Office of International Affairs, National Research Council (Loucks and Wu 1992; Wu and Loucks 1992a, b). We traveled together twice to the project meetings held in Wingspread, Racine, Wisconsin where he told me fascinating stories of the great American architect, Frank Lloyd Wright and pioneering Wisconsin ecologists.

Dr. Loucks was instrumental to the development of the "hierarchical patch dynamics paradigm", a topic on which we worked closely for several years (Wu and Loucks 1992a, b, 1995). As a continuation of our work on hierarchical patch dynamics, we also collaborated on a book on regional ecological analysis and spatial scaling (Wu et al. 2006). A great mentor inspires. For more than two decades, Dr. Loucks was a major source of inspiration and encouragement to me.

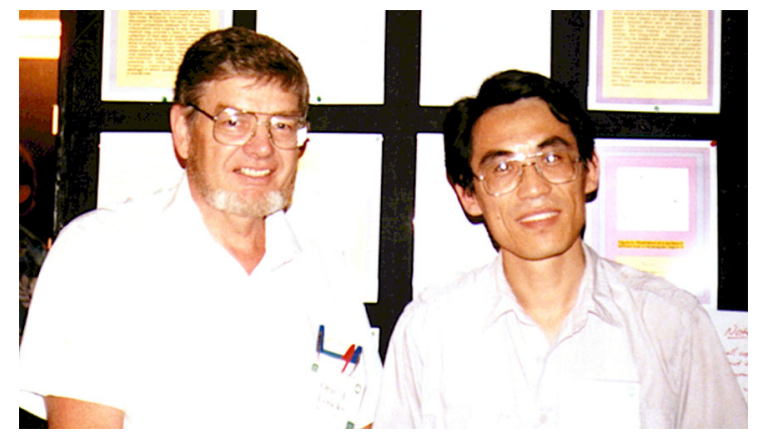

Orie Loucks and Jianguo $\mathrm{Wu}$ at the 77th Annual Meeting of the Ecological Society of America, Honolulu, Hawaii in August 1992. Orie almost always had three or four different-colored pens in his chest pocket and a notebook with him, so he took notes constantly while talking to people and traveling the world.

Dr. Loucks was the epitome of a transdisciplinary scholar. His contributions to ecology and the environment went beyond academia. As an environmental historian put it: Dr. Loucks "distinguished himself as a leading scholar in the field of applied ecology, focusing on the impact of human development on 
the environment", and was "a tireless and articulate crusader for environmental sanity long before the words 'ecology' and 'environment' had crept into the national vocabulary" (Kuhlberg 2009). For example, his testimony of the pesticide DDT being a persistent pollutant in soils, water and food webs was instrumental to the court ruling of banning the use of DDT in Wisconsin in 1969 and later in the entire United States in 1972. As the 2000 National Conservation Achievement Award recipient, he was described by the National Wildlife Federation as "a forester, ecologist and eminent professor" who was "one of the intellectual giants of the environmental movement" and "a leader in putting scientific knowledge to use in shaping real solutions for environmental problems" (Kuhlberg 2009).

Dr. Loucks was an ecologist who "thinks like a mountain" (to borrow Aldo Leopold's phrase). Many of his scientific ideas and ideals should and will be carried on into the future. As his legacy continues, he will be dearly missed. Farewell, Orie, and thank you forever.

\section{References}

Canham CD, Loucks OL (1984) Catastrophic windthrow in the presettlement forest of Wisconsin. Ecology 65(3):803-809

Jennings MD, Faber-Langendoen D, Loucks OL, Peet RK, Roberts D (2009) Standards for associations and alliances of the U.S. National Vegetation Classification. Ecol Monogr 79:173-199

Knight DH, Loucks OL (1969) A quantitative analysis of Wisconsin forest vegetation on the basis of plant function and gross morphology. Ecology 50(2):219-234

Kuhlberg M (2009) One hundred rings and counting: forestry education and forestry in Toronto and Canada, 1907-2007. University of Toronto Press, Toronto

Loucks OL (1962) Ordinating forest communities by means of environmental scalars and phytosociological indices. Ecol Monogr 32:137-166

Loucks OL (1970) Evolution of diversity, efficiency, and community stability. Am Zool 10:17-25

Loucks OL (1977) Emergence of research on agro-ecosystems. Annu Rev Ecol Syst 8:173-192

Loucks OL (1985) Looking for surprise in managing stressed ecosystem. Bioscience 35(7):428-432

Loucks OL (1990a) Land-water interactions. In: Patten BC (ed) Wetland and shallow continental water bodies. SPB Academic Publishing, The Netherlands, pp 243-258
Loucks OL (1990b) Predictive tools for rehabilitating linkages between land and wetland ecosystems. In: Wali MK (ed) Environmental rehabilitation. SPB Academic Publishing, The Netherlands, pp 369-380

Loucks OL (1994) Sustainability in urban ecosystems: beyond an object of study. In: Platt RH, Rowntree RA, Muick PC (eds) The ecological city. University of Massachusetts Press, Amherst, pp 49-65

Loucks OL, Armentano TV (1982) Estimating crop yield effects from ambient air pollutants in the Ohio river valley. J Air Pollut Control Assoc 32(2):146-150

Loucks OL, Galss GE (1986) Role of precipitation chemistry versus other watershed properties in Wisconsin Lake acidification. Water Air Soil Pollut 31:67-77

Loucks OL, Gorman RF (2004) Regional ecosystem services and the rating of investment opportunities. Front Ecol Environ 2(4):207-216

Loucks OL, Wu JG (1992) The Northeast. In: The US National Research Council (ed) Grasslands and grassland sciences in Northern China. National Academy Press, Washington D.C, pp 55-66

Loucks OL, Plumb-Mentjes ML, Rogers D (1985) Gap processes and large-scale disturbances in sand prairies. In: Pickett STA, White PS (eds) The ecology of natural disturbance and patch dynamics. Academic Press, San Diego, pp 71-83

Loucks OL, Erekson OH, Bol JW, Gorman RF, Johson PC, Krehbiel TC (1999) Sustainability perspectives for resources and business. Lewis Publishers, Boca Raton

MacCormick AJA, Loucks OL, Koonce JF, Kitchell JF, Weiler PR (1974) An ecosystem model for the pelagic zone of Lake Wingra. Oak Ridge National Laboratory, Oak Ridge

Mladenoff DJ, Burgess RL (1993) The pedagogical legacy of John. T. Curtis and Wisconsin plant ecology: 1947-1992. In: Fralish JS, McIntosh RP, Loucks OL (eds) John T. Curtis: fifty years of Wisconsin plant ecology. Wisconsin Academy Press, Madison, pp 145-196

Peet RK, Loucks OL (1977) A gradient analysis of southern Wisconsin forests. Ecology 58(3):485-499

Watson V, Loucks OL (1979) An analysis of turnover times in a Lake Ecosystem and some implications for system properties. In: Halfon E (ed) Theoretical systems ecology. Academic Press, New York, pp 355-383

Wu JG, Loucks OL (1992a) The Xilingol grassland. In: National Research Council (ed) Grasslands and grassland sciences in Northern China. National Academy Press, Washington D.C, pp 67-84

Wu JG, Loucks OL (1992b) The balance-of-nature and modern ecological theory: A shift in ecological thinking. In: SinoECO (ed) Advances in modern ecology. Science and Technology Press, Beijing, pp 16-29

Wu JG, Loucks OL (1995) From balance of nature to hierarchical patch dynamics: a paradigm shift in ecology. Q Rev Biol 70(4):439-466

Wu JG, Jones KB, Li HB, Loucks OL (eds) (2006) Scaling and uncertainty analysis in ecology: methods and applications. Springer, Dordrecht 